\title{
DOA PUASA DI ANTARA KEPEMIMPINAN PENGEMBALAAN, ROH KUDUS, DAN PERTUMBUHAN GEREJA
}

\author{
Sewie Elia Huang* \\ Sekolah Tinggi Alkitab Surabaya \\ *sewie@yahoo.com
}

\begin{abstract}
Fasting prayer has a very significant role for the growth of faith and congregation in the growth of the church because fasting prayer is their intimate relationship with God. The purpose of this paper answers the question: What is meant by fasting prayer? What is the relationship between fasting prayer and the Holy Spirit? What is the relationship between fasting prayer and shepherding leadership? What is the relation of fasting prayer in the growth of the Church? The research method uses descriptive literature research. The results of the study are: (1) fasting prayer is abstaining from all physical food for other bodies describing the consequences of fasting, namely: "suffering of the soul". (2) the relationship of fasting prayer with the Holy Spirit is fasting prayer which brings clarity of the way, the voice of the spirit, so that it will be sensitive to the voice of the Holy Spirit to provide guidance in obtaining spiritual and material victory as well. (3) the relationship of fasting prayer with the leadership of the shepherding is a servant of God who truly is a servant of God whose life of prayer is accompanied by fasting. (4) the relation of fasting prayer in the growth of the Church is the pastoral service can help realize the need for maturity and encourage growth in spirituality.
\end{abstract}

Keywords: fasting prayer; shepherd leadership; the Holy Spirit; church growth

\begin{abstract}
Abstrak
Doa puasa mempunyai peran yang sangatlah signifikan bagi pertumbuhan iman dan jemaatnya dalam pertumbuhan gereja karena doa puasa merupakan hubungan intim mereka dengan Allah. Tujuan penulisan ini menjawab pertanyaan: Apakah yang dimaksud dengan doa puasa? Bagaimanakah relasi doa puasa dengan Roh Kudus? Bagaimanakah relasi doa puasa dengan kepemimpinan pengembalaan? Bagaimanakah relasi doa puasa dalam pertumbuhan Gereja? Metode penelitian menggunakan penelitian deskriptif literature. Hasil penelitian adalah: (1) doa puasa adalah berpantang dengan semua makanan jasmani untuk tubuh yang lain menggambarkan akibat berpuasa, yaitu: "penderitaan jiwa". (2) relasi doa puasa dengan Roh Kudus adalah doa puasa mendatangkan kejernihan jalan, akan suara roh, sehingga akan peka dengan suara Roh Kudus untuk memberikan bimbingan memperoleh kemenangan rohani dan materi juga. (3) relasi doa puasa dengan kepemimpinan pengembalaan adalah seorang hamba Tuhan yang sungguh sungguh adalah hamba Tuhan yang hidup doanya disertai puasa. (4) relasi doa puasa dalam pertumbuhan Gereja adalah pelayanan penggembalaan dapat menolong menyadari kebutuhan akan kedewasaan dan mendorong bertumbuh dalam kerohanian.
\end{abstract}

Kata kunci: doa puasa, pemimpinan gembala, Roh Kudus, pertumbuhan gereja 


\section{PENDAHULUAN}

Dalam Alkitab banyak sekali dijumpai cerita mengenai puasa, baik yang dilakukan secara perorangan maupun yang dilakukan oleh seluruh bangsa secara serentak.Pada masa pemerintahan Yoyakhim bin Yosia raja Yehuda, telah diadakan penetapan puasa di hadapan Tuhan bagi segenap rakyat di Yerusalem dan bagi segenap rakyat yang telah datang dari kotakota Yehuda ke Yerusalem (Yer. 36:9). Juga puasa bangsa Israel dapat diketahui pada masa Ester, di mana orang-orang Israel hendak dibinasakan oleh Haman. Oleh karena doa puasa Ester dan orang-orang Israel, mereka dilepaskan dari ancaman (Est. 4:1-17; 5:1-8). Pada masa Ezra, saat orangorang Israel kembali ke Yerusalem dari pembuangan. mereka doa puasa meminta perlindungan dari Tuhan dalam perjalanan pulang. Tuhan melindungi dan dengan aman mereka sampai di Yerusalem (Ezr. 8:21-36). Masa Samuel, orang-orang Israel dikuasai orang-orang Filistin dan mereka menyembah para Baal dan para Asytoret. Nabi Samuel berkata orang-orang Israel ,"Apabila kamu berbalik kepada Tuhan dengan segenap hati, maka jauhkanlah para allah asing dan para Asytoret dari tengahtengahmu dan tujukan hatimu kepada Tuhan dan beribadalah hanya kepad-Nya, maka IA akan melepaskan kamu dari tangan orang Filistin".

Pada masa Yosafat, raja Yehuda datang menyerang orang-orang Yehuda. Yosafat menjadi takut, lalu mengambil keputusan untuk mencari Tuhan, ia menyerukan pada seluruh Yehuda supaya berpuasa. Kemudaian Allah berfirman melalui Yahaziel "janganlah kamu takut dan terkejut karena laskar yang besar ini, sebab bukan kamu yang akan berperang melainkan Allah, “...dalam peperangan ini tidak usah kamu bertempur..."

Tua-tua Jizreel juga berpuasa. Izebel, istri raja Ahab menulis surat atas nama Ahab, memeteraikannya dengan meterai raja, lalu mengirim surat itu kepada tua-tua dan pemuka-pemuka. Dalam surat itu dimaklumkan akan puasa dan untuk menghakimi Nabot pemilik kebun anggur. Nabot difitnah telah mengutuk Allah dan raja, padahal sebenarnya raja ingin memiliki kebun anggur Nabot. Tua-tua memaklumkan puasa dan menghakimi Nabot. Nabot dilempari batu sampai mati (1 Raj. 21:9-13). Ada juga empat puluh orang Yahudi di Yerusalem mau berpuasa dengan maksud untuk membunuh rasul Paulus. Mereka tidak mau makan dan minum sebelum Paulus dibunuh. Kebencian orangorang ini ditunggangi oleh iblis. Mereka membenci Injil. Injil menghendaki Injil keselamatan tidak dikabarkan. Demikian kehendak Iblis, hingga lebih dari 40 orang Yahudi bersumpah dengan mengutuk diri, tidak akan makan dan minum sebelum membunuh Paulus (Kis. 23:12-15).

Para pemimpin di dalam tugas melaksanakan panggilan Tuhan selalu disertai dengan doa puasa. Kebenaran puasa ini tidak hanya semata-mata ada dalam PL, tetapi terdapat juga dalam PB yang merupakan zaman anugerah. Kepemimpin mempunyai peran yang besar bagi arah suatu kelompok. Sebagaimana yang dikatakan oleh Eka Darmaputera. ${ }^{1}$ kepemimpinan yang baik merupakan syarat mutlak bagi pertumbuhan, kestabilan dan kemajuan kelompok apapun. Kepemimpinan tidak terelakkan di dalam menghadapi kenyataan. Di dalam kenyataan hidup, tidak lepas menghadapi tantangan hidup, di mana

${ }^{1}$ Eka Darmaputera, Kepemimpinan Kristiani (Jakarta: STT Jakarta, 2001), 1. 
setiap pribadi maupun secara bersama harus menyusun suatu rancangan, baik manajemen dan strategi yang tepat serta memberi keputusan agar dicapai hasil yang baik. Untuk memberikan hasil yang baik tentunya memerlukan jiwa kepemimpinan. Sebab apabila tidak ada seorang yang berjiwa kepemimpinan yang baik, bisa membawa akibat yang fatal.

Kepemimpinan yang baik yang mempunyai pemahaman sebagai Pemimpin yang tahu jelas panggilannya sebagai Gembala yang dalam arti sebenarnya sebagai Gembala dalam bahasa Yunani "Poimen" yang menggembalakan dombadomba sesuai dengan Yehezkiel 34. Seperti yang dikatakan oleh Dr. Sudomo, peran pemimpin sangat besar dalam menentukan maju mundurnya suatu lembaga atau organisasi, baik sekuler maupun rohani, baik besar maupun kecil, bahkan bangsa dan negara. $^{2}$ Nilai-nilai etika Kristen wajib digali dalam berdasarkan adalah: kehidupan, tindakan, ajaran dan karya Yesus Kristus melalui Alkitab. ${ }^{3}$ Juga peran pemimpin di dalam gereja, pemimpinan gereja yang tidak mampu memerankan posisi strategisnya, tak dapat disangkal, banyak menimbulkan berbagai persoalan dalam gereja. ${ }^{4}$ Demikian juga dikatakan oleh John Edmund Haggai, Pendiri Haggai Institute, "Panggilan terhadap para pemimpin adalah perlu, sebab dunia ini sedang mengalami krisis kepemimpinan. Krisis tersebut mengalir dari pemimpin perusahaan, pemerintahan,

\footnotetext{
${ }^{2}$ Sudomo, Ciri Utama Kepemimpinan Sejati (Jakarta: CBA Indonesia, 2005), 11.

${ }^{3}$ Harianto GP, Studi Etika Pendidikan Tentang Proses Belajar-Mengajar Yang Mengubah Karakter Dan Kurikulum 2013. Stulos. Vol. 12.No. 1 39-64.

http://www.sttb.ac.id/download/stulos/2013/April/Stu los.

${ }^{4}$ Ibid, 11.
}

mimbar gereja-gereja sampai pada pemimpin lokal. Pada setiap jajaran, masyarakat mengharapkan adanya pemimpin". 5

Perlunya seorang pemimpin tidaklah cukup, seorang pemimpin harus dibekali dengan kemampuan untuk memimpin. Apabila ini tidak terpenuhi, maka bisa menimbulkan masalah juga. Father Anthony D'Sauza mengatakan, "Apakah masalah terbesar yang dihadapi oleh semua organisasi? Jawabnya mudah, yaitu kurangnya keterampilan memimpin dan mengelola sumber daya manusia. Mungkin sebenarnya hal itu sangat nyata. Namun sayang sekali kebanyakan orang tidak melihatnya sering tidak dapat melihatnya". ${ }^{6}$

Pemimpin bukan saja mempunyai keahlian memimpin, tetapi ia harus mempunyai kemampuan doa puasa. Alasan puasa adalah: (1) secara khusus adalah: unsur ibadah dalam Kerajaan Allah (Mat. 6:1-18), kehendak Tuhan Yesus (Mat. 9:1417), ${ }^{7}$ Teladan Tuhan Yesus (Mat. 4:1-11, Luk. 4:1,2), statement Tuhan Yesus, persembahan Tubuh (Rm. 12:1-2). secara umum: persiapan memulai Pelayanan (Kis. 13:2-3), iman dikuatkan (Mat. 17:1921), senantiasa dipenuhi Roh Kudus, untuk dipakai oleh Allah, ${ }^{8}$ hidup dalam kesucian, pembukaan rahasia Firman Allah, mendapat pertolongan Tuhan, dan pelayanan occultisme. Dengan demikian maka pemimpin yang mempunyai doa puasa

${ }^{5}$ John Haggai, Lead On! Leadership That Endures in A changing World (Waco Texas: World Publishing, 1986), 14.

${ }^{6}$ Anthony D'Sauza, Developing The Leader Within You, Strategies for Effective Leadership (Singapore: Haggai Centre for Advanced Leadership Studies, 1994), 18.

${ }^{7}$ Arthur Wallis, God's Chosen Fast (Pennsylvania: Christian Literature Crusade, 1971), 25.

${ }^{8}$ Ibid, 54. 
adalah pemimpin yang selalu berkomunikasi dengan Tuhan. Dengan mengalami doa puasa bahkan doa puasa menjadi gaya hidup, maka gereja yang dipimpinnya akan bertumbuh. Dengan bertumbuh, maka gereja tersebut akan mengutus anak-anak Tuhan untuk memberitakan Injil Kristus.

Tujuan penulisan ini menjawab pertanyaan: Apakah yang dimaksud dengan doa puasa? Bagaimanakah relasi doa puasa dengan Roh Kudus? Bagaimanakah relasi doa puasa dengan kepemimpinan pengembalaan? Bagaimanakah relasi doa puasa dalam pertumbuhan Gereja?

\section{METODE PENELITIAN}

Metode penelitian menggunakan penelitian deskriptif literature. Penelitian Literatur menggembangkan kemampuan analisis literature (analisis isi atau dokumentasi), artinya kajian yang menekanakan pada analisis bahan tertulis sesuai konteksnya. Penelitian jenis untuk menggali pikiran seseorang yang tertuang di dalam buku atau literatur-Literatur yang terpublikasikan. ${ }^{9}$

\section{PEMBAHASAN}

\section{Pengertian Doa Puasa}

Puasa dalam bahasa Yunani "Nesteis", terdiri dari dua bagian: awalan negatif "ne" dan kata kerja "esthio" yang berarti makan. Perkataan ini seringkali diterjemahkan "berpantangan makan secara sukarela". Sedangkan puasa di dalam PL, ada dua perkataan Ibrani yang mempunyai hubungan dengan perbuatan puasa, yang pertama berarti "berpantang dengan semua makanan jasmaniuntuk tubuh" yang lain

${ }^{9}$ Mudjia Rahardjo, Jenis dan Metode Penelitian Kualitatif, Tuesday, 01 June 2010 04:52, http://mudjiarahardjo.uin-malang.ac.id/karyailmiah/215.html?task=view. menggambarkan akibat berpuasa, yaitu: "penderitaan jiwa" .Jika digabungkan, kedua perkataan itu mengandung pengertian: menghilangkan kesenangan tubuh secara sukarela. Dan merendahkan jiwa untuk maksud-maksud rohani. ${ }^{10}$

Puasa merupakan bagian dari penggembalaan. Paul Yonggi Cho mengatakan: "Puasa adalah dengan sukarela dan dengan sengaja tidak makan dan minum, dengan tujuan supaya dapat memusatkan pikiran terhadap Tuhan. ${ }^{11}$ Flory mengatakan puasa adalah: "Sebagian atau secara total meniadakan keinginan yang biasa untuk tujuan mempersembahkan waktu bagi pertumbuhan "manusia" dan untuk memertajam indra rohani guna menghadapi peperangan rohani". ${ }^{12}$ Puasa menurut Mimery menyebut: "Meninggalkan kebiasaan-kebiasaan hidup seketika lamanya karena kepentingan jiwa orang itu menuntut pemusatan pikiran yang lebih besar". ${ }^{13}$ Stott mengatakan bahwa dalam arti sempitnya menjalankan puasa berarti total tidak makan dan minum. ${ }^{14}$ Lebih tajam, Calvin mengatakan bahwa berpuasa itu melatih seseorang dalam berpantang, dalam menekan nafsu daging, mengobarkan semangat untuk rajin berdoa, dan itu adalah suatu tanda bukti penyesalan. ${ }^{15}$ Berlanjut, Agustinus disebut fletus at hymnus yang berarti menangis dan memuji. Menangisi

\footnotetext{
${ }^{10}$ James Lee Beal, Puasa (Bandung: Penerbit Kalam Hidup, 1980), 15.

${ }^{11}$ Paul Yonggi Cho, Doa Kunci Ke Arah Kebangunan Rohani (Jakarta: YPI Immanuel, 1986), 149.

${ }^{12}$ R.D Flory, Tuntunan Doa Puasa, (New York: Used - Acceptable, 2000), 1.

${ }^{13}$ Nehemiah Mimery, Rahasia Tentang Doa (Jakarta: Nehemiah Mimery Press, 1969), 62.

${ }^{14}$ John R.W.Stott, Khotbah di Bukit (Jakarta: Yayasan Komunikasi Bina Kasih/OMF, 1990), 28.

${ }^{15}$ J.Verkuyl, Khotbah di Bukit (Jakarta: BPK Gunung Mulia, 1989), 103.
} 
pelanggaran-pelanggaran yang menyebabkan Juruselamat tersentuh hatiNya. Dan mengucapkan puji- pujian, yang dengan tenangnya naik ke atas ke hadirat Bapa, karena Bapa menyertai dan menaruh kasih setia-Nya lagi kepada setiap manusia. ${ }^{16}$

Para pemimpin dalam Alkitab yang berpuasa adalah: Yesus memulai pelayananNya dengan berdoa dan berpuasa selama 40 hari. Setelah Yesus berpuasa selam empat puluh hari dan empat puluh malam, akhirnya laparlah Yesus, lalu datanglah Iblis mencobai Yesus. Yesus dicobai dan diserang dalam tiga area yaitu daging, dunia dan Iblis. ${ }^{17}$ Yesus memperoleh kemenangan, karena Ia telah mempersiapkan diri dengan berdoa dan berpuasa dan juga menggunakan firman Allah yang tertulis (Mat. 4:1-11).

Musa merupakan satu-satunya nabi yang dua kali berpuasa selama empat puluh hari dan empat puluh malam tanpa makan dan minum. Puasa pertama Musa, pada saat ia di gunung untuk menerima lh- loh batu, loh-loh perjanjian yang diikat Tuhan dengan bangsa Israel. Tuhan sendiri yang memberikan kepada Musa kedua loh batu, yang ditulis oleh $\mathrm{j}$ ari Allah, segala firman yang diucapkan $\mathrm{T}$ uhan kepada bangsa Israel di gunung dari tengah-tengah api.

Elia. Izebel mau membunuh Elia, disebabkan Elia telah membunuh semua nabi-nabi Baal dengan pedang. Elia takut dan ia melarikan diri ke padang gurun. Ia mengalami kelemahan, tetapi malaikat Tuhan datang dan memberikan kekuatan kepadanya dengan roti dan kendi berisi air. Oleh kekuatan makanan itu ia berjalan empat puluh hari empat puluh malam lamanya sampai ke gunung Allah yaitu

\footnotetext{
${ }^{16}$ Ibid, 102.

${ }^{17}$ R.D Flory, Tuntunan Doa Puasa, (New York: Used - Acceptable, 2000), 9.
}

gunung Horeb. Allah menyatakan dirinya kepada Elia, untuk memberikan kekuatan kepadanya (1 Raj. 19:1-18).

Daniel dipilih oleh raja Nebukadnezar raja Babel untuk bekerja dalam istana raja, ia hanya makan sayur dan air putih.Pada saat itu Daniel berketetapan untuk tidak menajiskan dirinya dengan santapaan raja dan anggur yang biasa diminum raja, ia hanya makan sayur dan air putih. Dan Allah mengaruniakan kepada Daniel kasih sayang dari pemimpin pegawai istana, juga Allah memberikan Daniel pengetahuan dan kepandaian tentang berbagai-bagai tulisan dan hikmat, juga mempunyai pengertian tentang berbagaibagai penglihatan dan mimpi. Daniel di dalam kehidupannya selalu tidak terlepas dari persekutuan dengan Allah tiga kali sehari, ia berlutut berdoa serta memuji Allah seperti yang biasa dilakukannya (Dan. 6:11).

Ester. Haman seorang pembesar yang diangkat raja Ahasyweros merencanakan untuk memunahkan orang Yahudi. Ia memfitnah bangsa Israel di hadapan raja, sehingga raja mengeluarkan surat titah untuk membinasakan orang Yahudi. Mordekhai mengetahui hal ini, memberitahu Ester, keluarga mordekhai yang menjadi ratu Ahasyweros untuk membatalkan rencana Haman yang jahat itu. Ester memberitahu kepada mordekhai melalui utusannya, bahwa ada undangundang kerajaan yang menghukum mati siapa saja yang berani menghadap raja tanpa diundang. Hanya orang yang kepadanya raja mengukir tongkat emas akan tetap hidup.

Nehemiah bekerja di istana Raja Artahsastra. Ketika Nehemia mendengar tentara Yerusalem dimana temboknya terbongkar dan pintu-pintun gerbangnya terbakar, duduklah Nehemia menangis berdoa dan berpuasa selama beberapa hari di 
hadapan hadirat Allah. Ia berdoa memohon pengampunan dosa bangsanya dan pembangunan kembali Yerusalem. Sebagai hasil doanya, Allah bekerja dalam hati raja Artahsartra, mengabulkan permohonan Nehemiah untuk mengutusnya ke Yehuda, untuk membangun kembali kota Yerusalem, Dan Nehemiah memimpin pembangunan kembali reruntuhan kota Yerusalem (Neh. $1: 1-11 ; 2: 1-8)$.

Ezra. Pada saat bangsa Israel kembali ke Yerusalem dari tawanan di Babel, Ezra menghimpunkan orang-orang Israel dan beberapa pemimpin untuk berangkat pulang. Di tepi sungai Ahawa, Ezra memaklumkan puasa supaya bangsa Israel merendahkan diri di hadapan Allah dan memohon kepada-Nya jalan yang aman bagi mereka, bagi anak-anak mereka dan segala harta benda mereka. Sebab Ezra malu meminta tentara dan orang- orang berkuda kepada raja untuk mengawal mereka terhadap musuh di jalan; sebab mereka telah berkata kepad raja bahwa tangan Allah Israel melindungi mereka. Jadi mereka berpuasa dan memohon hal itu kepada.

Daud. Tuhan mengutus Natan kepada Daud. Ia datang untuk memperingati Daud. Daud telah berbuat dosa mengambil istri Uria dan Uria diutus ke medan peperangan, sehingga tewas. Dan karena perbuatannya telah menista Tuhan, maka Natan mengatakan bahwa anak yang lahir bagi Daud dari istri Uria itu akan pasti mati. Akhirnya anak Daud ini sakit. Daud memohon kepada Allah oleh karena anak itu, ia berpuasa dengan tekun dan semalammalaman ia berbaring di tanah.

Murid-Murid Yohanes datang kepada Yesus dan berkata: "Mengapa kami dan orang Farisi berpuasa, tetapi muridmuridmu tidak"? Yesus menjawab: "Dapatkah sahabat-sahabat mempelai laki- laki berdukacita selama mempelai itu bersama mereka? Tetapi waktunya akan datang, mempelai itu diambil dari mereka dan pada waktu itulah mereka akan berpuasa" (Mat. 9:14-15). Yang dimaksud Yesus tentang mempelai laki-laki di sini adalah diri Yesus sendiri (Why. 21:9). Yesus menyatakan bahwa pada saat kenaikan-Nya ke surga, saat itulah muridmurid-Nya akan berpuasa. Dan ini benarbenar dibuktikan pada masa gereja mulamula. Dalam hal ini bukan berarti pada masa Yesus murid- murid-Nya tidak berpuasa. Yesus mengajarkan kepada murid-muridNya di bukit tentang kebenaran ibadah yaitu doa. Puasa dan memberi yang harus dilakukan secara benar, bukannya seperti orang farisi yang menonjolkan kesalehan puasanya. Murid-murid Yohanes melakukan puasa, jelas puasanya berkenan kepada Tuhan, karena sepanjang kehidupan Yesus tidak pernah Ia menegur puasa dari muridmurid Yohanes.

Dari uraian tersebut dapat disimpulkan bahwa puasa adalah berpantang dengan semua makanan jasmani untuk tubuh yang lain menggambarkan akibat berpuasa, yaitu: "penderitaan jiwa". Puasa menghilangkan kesenangan tubuh secara sukarela dan merendahkan jiwa untuk maksud-maksud rohani.

\section{Relasi Doa Puasa dengan Roh Kudus}

Tuhan Yesus pernah bersabda kepada murid-murid-Nya bahwa apabila mempelai laki-laki itu diangkat, pada saat itulah sahabat-sahabat mempelai akan berpuasa (Mrk. 2:18-22). Mempelai laki-laki yang dimaksudkan oleh Yesus adalah dirinNya sendiri. Yesus telah berkata, bahwa pada saat kenaikan-Nya ke Surga, pada saat itulah murid-murid- Nya akan berpuasa. Pada saat Yesus akan naik ke Surga Ia 
berkata "...kamu akana menerima kuasa, kalau Roh Kudus turun ke atas kamu, dan kamu akan menjadi saksi-Ku di Yerusaalem dan diseluruh Yudea dan Samaria dan sampai ke ujung bumi” (Kis.1:8). Sesudah murid-murid Yesus menyaksikan kenaikan Yesus ke Surga, mereka kembali ke Yerusalem. Sesuai dengan pesan Yesus yang melarang mereka meninggalkan Yerusalem, dan menyuruh mereka tinggal di situ menantikan janji Bapa (Kis. 1:4).

Gereja mula-mula untuk mengetahui pimpinan Tuhan. Mereka berdoa dan puasa. Saat mereka doa puasa, Roh kudus memberikan petunjuk kepada sidang jemaat Tuhan: "Khususkanlah Barnabas dan Saulus bagi-Ku untuk tugas yang telah kutentukan bagi mereka”. Maka berpuasa dan berdoalah mereka, dan setelah meletakkan tangan kea atas kedua orang itu, mereka mebiarkan keduanya pergi (Kis. 13:1-3). Dengan doa puasa ini mereka peka akan suara Roh Kudus. Saat Barnabas dan Saulus dalam penginjilan, dan mulai mendirikan sidang jemaat yang baru, di tiap-tiap jemaat, rasulrasul menetapkan penatua-penatua, setelah berdoa puasa, mereka menyerahkan penatua-penatua itu kepada Tuhan yang adalah sumber kepercayaan mereka (Kis. 14:21-23). Rasul-rasul juga mengajarkan kepada orang-orang percaya untuk berdoa dan berpuasa, seperti yang mereka lakukan di Antiokhia. Berdoa dan berpuasa merupakan bagian yang vital dalam memperoleh bimbingan dari Roh Kudus sebelum menjabat suatu kedudukan kepemimpinan dalam gereja Tuhan. Doa puasa mendatangkan kejernihan jalan, akan suara roh, sehingga akan peka dengan suara Roh Kudus untuk memberikan bimbingan memperoleh kemenangan rohani dan materiil juga. Maka perlu adanya persekutuan dengan Roh Kudus.
Persekutuan berarti "berkomunikasi dengan atau bepergian bersama-sama, mengangkut dengan". ${ }^{18}$

Alkitab dengan jelas mengajarkan bahwa Roh Kudus menolong seseorang dalam doa-doanya. "Demikian juga Roh membantu dalam setiap kelemahan yang ada; sebab tidak akan tahu, bagaimana sebenarnya harus berdoa; tetapi Roh sendiri berdoa untuk menuntun kepada Allah dengan keluhan-keluhannya yang tidak terucapkan" (Rm. 8:26). Yudas 2 juga menunjukkan kedudukan Roh Kudus dalam kehidupan kita: "Akan tetapi saudarasaudaraku yang kekasih, bangunlah dirimu sendiri diatas imanmu yang paling suci dan berdoalah dalam Roh Kudus".

Roh Kudus seorang sahabat setia yang datang untuk melakuklan segala sesuatu yang disebutkan firman akan dilakukan-Nya. Dengan memohon kepadanNya untuk menjadi adimitra dalam semua hal yang menyangkut kehidupan pribadi dan pekerjaan Tuhan. Dengan demikian bila tiba saat menyediakan khotbah, Ia selalu hadir. Ketika saat memberikan nasihat, Ia mengarahkan nasihat kepada setiap pribadi. "Dan bila Ia memegang kendali dalam kebaktian, kehadiran-Nya sangat menentukan keberhasilan kebaktian itu."19 Bound berkata, "Apa yang diperlukan gereja sekarang ini bukanlah mesin-mesin yang lebih banyak atau yang lebih baik, bukan pula organisasi- organisasi dan cara-cara yang baru, melainkan orang-orang yang dapat dipakai oleh Roh Kudus, orang-orang yang suka berdoa, orang-orang yang memiliki kuasa di dalam doa. Roh Kudus tidak mengalir melalui cara-cara yang baru (sekalipun hal itu baik juga), melainkan

${ }^{18}$ Paul Yonggi Cho, Roh Kudus Adalah Mitra Saya (Jakrta: YPI Imanuel, 2002), 13.

${ }^{19}$ Ibid, 14. 
melalui manusia. Ia tidak datang kepada mesin- mesin, melainkan kepada manusia. Roh Kudus tidak mengurapi, rencanarencana saja, tetapi mengurapi manusiamanusia yang suka berdoa". ${ }^{20}$

Dari uraian di atas dapat disimpulkan bahwa relasi doa puasa dengan Roh Kudus ialah doa puasa mendatangkan kejernihan jalan, akan suara roh, sehingga akan peka dengan suara Roh Kudus untuk memberikan bimbingan memperoleh kemenangan rohani dan materi juga. Maka perlu adanya persekutuan dengan Roh Kudus. Persekutuan Roh Kudus memimpin tiap hari dan persekutuan terus menerus dengan Roh Kudus penting untuk kesejahteraan rohani. Roh Kudus memimpin hati ke dalam anugerah dan cinta, iman. Roh Kudus sebagai sahabat setia yang datang untuk melakuklan segala sesuatu yang disebutkan firman akan dilakukan-Nya.

\section{Relasi Doa Puasa dengan Kepemimpinan Pengembalaan}

Kepemimpin mempunyai peran yang besar bagi arah suatu kelompok. Sebagaimana yang dikatakan oleh Eka Darmaputera, kepemimpinan yang baik merupakan syarat mutlak bagi pertumbuhan, kestabilan dan kemajuan kelompok apapun. ${ }^{21}$ Kepemimpinan tidak terelakkan di dalam menghadapi kenyataan. Di dalam kenyataan hidup, tidak lepas menghadapi tantangan hidup, di mana setiap pribadi maupun secara bersama harus menyusun suatu rancangan, baik manajemen dan strategi yang tepat serta memberi keputusan agar dicapai hasil yang baik. Untuk memberikan hasil yang baik tentunya

${ }^{20}$ E, M. Bounds, Power Through Prayer. (New York; Simon and Schuster, 1997), 6.

21 Eka Darmaputera. Kepemimpinan Kristiani. (Jakarta: STT Jakarta, 2001), 1. memerlukan jiwa kepemimpinan. Sebab apabila tidak ada seorang yang berjiwa kepemimpinan yang baik, bisa membawa akibat yang fatal. Panggilan kepemimpinan adalah panggilan penentu, mempunyai arah terkonsep.

\section{Kepemimpinan Berkonsep}

Kepemimpinan pengembalaan yang baik yang mempunyai pemahaman sebagai Pemimpin yang tahu jelas panggilannya sebagai Gembala yang dalam arti sebenarnya. Gembala dalam bahasa Yunani "Poimen" yang menggembalakan dombadomba sesuai dengan Yehezkiel 34. Kurangnya pemahaman atau gagal paham mengenai kepemimpinan pengembalaan akan berakibat fatal, seperti seringkali ketika pendiri suatu gereja telah meninggal, dan pada masa suksesi kepemimpinan terjadi konflik kepemimpinan yang menjadi sejarah hitam yang terjadi bagi Gereja tersebut, di mana akhirnya banyak anggota jemaat keluar.

Seperti yang dikatakan oleh Dr. Sudomo, peran pemimpin sangat besar dalam menentukan maju mundurnya suatu lembaga atau organisasi, baik sekuler maupun rohani, baik besar maupun kecil, bahkan bangsa dan negara. ${ }^{22}$ Juga peran pemimpin di dalam gereja, pemimpin gereja yang tidak mampu memerankan posisi strategisnya, tak dapat disangkal, banyak menimbulkan berbagai persoalan dalam gereja. ${ }^{23}$ Demikian juga dikatakan oleh John Edmund Haggai, Pendiri Haggai Institute, "Panggilan terhadap para pemimpin adalah perlu, sebab dunia kita sedang mengalami krisis kepemimpinan. Krisis tersebut mengalir dari pemimpin perusahaan,

22 Sudomo, Ciri Utama Kepemimpinan Sejati. (Jakarta: CBA Indonesia, 2005), 11.

${ }^{23}$ Ibid., 11. 
pemerintahan, mimbar gereja-gereja sampai pada pemimpin lokal. Pada setiap jajaran, masyarakat kita mengharapkan adanya pemimpin". ${ }^{24}$

Perlunya seorang pemimpin tidaklah cukup, seorang pemimpin harus dibekali dengan kemampuan untuk memimpin agar menjadi pemimpin yang memiliki konsep sesuai panggilannya. Apabila ini tidak terpenuhi, maka bisa menimbulkan masalah juga. Father Anthony D'Sauza mengatakan, "Apakah Anda tahu masalah terbesar yang dihadapi oleh semua organisasi? Jawabnya mudah, yaitu kurangnya keterampilan memimpin dan mengelola sumber daya manusia. Mungkin sebenarnya hal itu sangat nyata. Namun sayang sekali kita sering tidak dapat melihatnya." 25

\section{Kepemimpinan Gembala}

Tuhan memanggil para pemimpin Gereja untuk mengembalakan jemaat, ini yang prinsipil. Panggilan terhadap pemimpin Gereja adalah panggilan yang indah, seperti yang dikatakan oleh Rasul Paulus kepada Timotius, "Benar perkataan ini: "Orang yang menghendaki jabatan penilik jemaat menginginkan pekerjaan yang indah" (1 Tim. 3:1). Rasul Petrus mengatakan kepada para gembala jemaat, "Gembalakanlah kawanan domba Allah yang ada padamu, jangan dengan paksa, tetapi dengan sukarela sesuai dengan kehendak Allah, dan jangan karena mau mencari keuntungan, tetapi dengan pengabdian diri. Janganlah kamu berbuat seolah-olah kamu mau memerintah atas

${ }^{24}$ John Haggai, Lead On! Leadership That Endures in A changing World. (Waco Texas: World Publishing, 1986). 23

25 Anthony D'Sauza, Developing The Leader Within You, Strategies for Effective Leadership (Singapore: Haggai Centre for Advanced Leadership Studies, 1994), 32. mereka yang dipercayakan kepadamu, tetapi hendaklah kamu menjadi teladan bagi kawanan domba itu" (1 Ptr. 5:2-3). Perkataan Rasul Petrus ini bukanlah sematamata perkataan teoritis saja, melainkan ia telah melaksanakan pelayanan pengembalaan dengan sepenuh hati sebagai wujud kasihnya kepada Tuhan Yesus. Sebagaimana Tuhan Yesus pernah bertanya kepada Petrus tentang kasihnya kepada-Nya, "Simon apakah engkau mengasihi Aku lebih daripada mereka ini?" Jawab Simon, "Benar Tuhan, Engkau tahu, bahwa aku mengasihiEngkau!". Jawab Tuhan Yesus kepada Petrus, "Gembalakanlah domba-dombaKu!" (Yoh. 21:15-19). Pertanyaan ini diajukan sampai tiga kali, menunjukkan betapa mulianya pelayanan kepemimpinan pengembalaan, karena pelayanan ini merupakan wujud kasih kita kepada Tuhan.

Jelas panggilan kepemimpinan, baik kepemimpinan sekuler maupun gerejani mempunyai peran yang besar. Di dalam bergerejani, kepemimpinan pengembalaan mempunyai peran yang penting di dalam pertumbuhan, kestabilan dan kemajuan jemaat gerejani. Rasul Petrus sadar peran kepemimpinan pengembalaan sangat penting dan adalah suatu perintah agung dari Tuhan Yesus sendiri, perlu dilaksanakan dengan baik, sebab itu Rasul Petrus katakan kepada para pemimpin gembala jemaat, "Gembalakanlah kawanan domba Allah yang ada padamu, ... tetapi hendaklah kamu menjadi teladan bagi kawanan domba itu" (1 Ptr. 5:2-3). Untuk bisa menjadi teladan yang baik, pemimpin Kristen perlu dibekali dengan kemampuan memimpin dengan baik dan memiliki kerohanian yang baik, karena pengembalaan adalah tugas rohani. Seperti Rasul Paulus menasehati Timotius untuk menjadi teladan dalam tugas mengarahkan para Penatua, "Jadilah teladan di dalam 
perkataan, perilaku, kasih, kesetiaan dan kekudusan" 5 prinsip utama yang sangat prinsipil di dalam panggilan melaksanakan kepemimpinan pengembalaan.

\section{Pemimpin yang melakukan Doa Puasa}

Pada pengajaran Yesus yang pertama di dalam pelayanan-Nya yang dikenal dengan "Khotbah Yesus di atas Bukit". Yesus adalah Maha Guru, mengajar umat-Nya dengan tujuan untuk membentuk karakter Illahi. Dalam pengajaran, Yesus tidak membicarakan tentang sistem kerajaan duniawi, organisasi strategi, pembentukan kekuatan militernya; tetapi mengenai Kerejaan Allah yang tidak akan binasa. Di dalam Kerajaan Allah ini Yesus memberikan hukum-hukum untuk membentuk umat-Nya yang layak tinggal dalam kerajaan-Nya. Pengajaran tentang puasa adalah pengajaran Tuhan Yesus di dalam "Khotbah di atas bukit". Puasa merupakan hukum kebenaran ibadah yang Yesus ajarkan kepada umat-Nya. ${ }^{26}$

Doa puasa yang demikianlah yang Tuhan kehendaki. Memperhatikan orang lain dan mengasihi jiwa-jiwa yang terhilang. Musa di dalam penggembalaannya atas bangsa Israel, di tengah-tengah pelayannanya ia juga berpuasa. Sepanjang sejarah Alkitab banyak tokoh-tokoh Alkitab, di dalam tugas dan pelayannanya yang berhubungan dengan umat, selalu tidak lepas dari puasa. Dalam tugas menggembalakan domba-domba Tuhan, Ishak Lew L.S mengatakan, "Seorang gembala sidang harus mengambil teladan dari Tuhan Yesus yang menjadi gembala yang baik. Gembala yang baik itu menyerahkan nyawanya, ganti segala domba

${ }^{26}$ Timotius Subekti, Khotbah Tuhan Yesus Pembentuk Karakter Ilahi (Yogjakarta: Andi, 1986), 102. itu, artinya ada roh korban untuk keselamatan dan pemeliharaan dari dombadombanya. Tuhan Yesus menyerahkan nyawa-Nya. Jadi seorang Gembala sidang harus memusatkan pikirannya untuk menggembalakan domba-dombanya, yang dipercayakan oleh Tuhan. Karena itu seorang gembala sidang yang ingin memiliki tabiat kasih dari Kristus, harus melalui sembahyang dan puasa. Korban lapar, korban lelah, korban merasa tubuhnya tidak tahan. Tuhan melihat hati, ingin ada roh Gembala sidang, maka Tuhan akan memberi tabiat Kasih dan dapat mengasihi jiwa-jiwa semestinya."27

Berkaitan hal tersebut pemimpin dapat merelasikan doa puasa terhadap dirinya endiri maupun jemaatnya sebagai berikut: Pertama, pelayanan mimbar. Pelayanan mimbar mempunyai tiga kutub, yaitu; Pengkhotbah, Firman Allah dan jemaat. Antara ketiga kutub ini mempunyai hubungan yang erat. ${ }^{28}$ Penghkotbah adalah pelayan Firman yang diutus, ia melakukan pelayanan atas nama Allah, dan dengan kewibaan yang ia peroleh dari Allah. Ia mendapat tugas untuk memberitakan Firman Allah, sebagai pelayaan dari Allah yang berfirman. ${ }^{29}$ Ia bertugas menyampaikan berita itu, berita yang ia terima dari Allah, dan ia sampaikan dengan sebaik- baiknya dan semurni-murninya kepada jemaat.

Pengkhotbah sebagai pelayan Tuhan adalah seperti pipa emas, melalui pipa itu minyak ilahi mengalir. Pipa emas itu harus terbuka lebar- lebar dan tetap bersih, supaya minyak dapat mengalir sepenuhnya dengan

\footnotetext{
${ }^{27}$ Ishak Lew, Membangun Sidang Jemaat (Surabaya: Sekolah Elkitab Surabaya, 1981), 3.

${ }^{28}$ Debora Kurniasari, Pengerja Mimbar (Surabaya: Diktat Sekolah Elkitab Surabaya, 1980), 22.

${ }^{29}$ Ibid, 23.
} 
tidak terhalang dan terbuang. Khotbah itu suci jika pengkhotbahnya suci. Khotbah itu penuh kuasa, jika pengkhotbahnya juga penuh kuasa. Penuh urapan Roh Kudus, jika pengkhotbahnya juga penuh urapan. Khotbah itu bertumbuh dan hidup, jika pengkhotbahnya bertumbuh dan hidup. Khotbah adalah pancaran dari suatu kehidupan. Pengkhotbah yang menjadikan doa puasa suatu faktor yang ampuh dalam kehidupan dan pelayanannya sendiri adalah orang yang kuat dalam pekerjaan Allah dan penuh kuasa untuk melebarkan Kerajaan Allah di dunia ini. Doa puasa dapat membantu manusia bagi Allah. Doa puasa dapat membentuk pengkhotbah dan seorang gembala sidang. ${ }^{30}$ Roh Kudus hanya mengurapi pengkhotbah yang suka berdoa (Kis. 2:1-47). Doa yang sungguh-sungguh selalu disertai doa puasa. Pengkhotbah yang penuh urapan Roh Kudus adalah pengkhotbah yang dibentuk dalam jam- jam doa dan puasa.

Firman Allah yang ditaburkan pengkhotbah haruslah firman yang terdapat dalam Alkitab. "Firman-Mu pelita bagi kakiku terang bagi jalanku" (Mzm. 119:105). Tanpa firman itu manusia hidup dalam kegelapan, sehingga gampang tersesat. J.L.Ch. Abineno mengatakan: "Maksud Tuhan Allah memberikan Alkitab kepada manusia ialah supaya setiap manusia pertama-tama menggunakan sebagai buku pemberitaan, sebab ia mengandung amanat yang harus disampaikan kepada jemaat. Alkitab adalah satu-satunya sumber pemberitaanseorang pelayan. Karena itu tidak boleh menyimpang daripadanya. Kalau pada hari minggu berdiri di belakang Alkitab menghadap jemaat, harus

${ }^{30}$ J. L. Ch. Abineno, Pelayanan dan Pelayan Jemaat Jemaat Dalam Perjanjian Baru (Jakarta: BPK Gunung Mulia, 1986), 97. berkhotbah tentang apa yang tertulis di dalamnya."68

Pengkhotbah yang menyampaikan Firman Tuhan, bukan saja perkataan, tetapi juga perbuatan. Pada saat Yesus dicobaioleh iblis di padang gurun, Firman yang Tuhan Yesus ucapkan dikutip dari PL. Iblis pun mengucapkan firman yang dikutip dari PL. Tetapi adad bedanya, Yesus mendasari Firman Tuhan di dalam doa puasa, sehingga firman itu hidup dan penuh kuasa, dan tepat pada sasarannya (Mat. 4:1-6).

Kutub ketiga adalah jemaat. Jemaat datang ke gereja dengan berbagai latar belakang, juga dengan berbagai masalah masing-masing. Tentunya mereka amengharapkan mendapat jawaban dari Firman Tuhan. Untuk mempersiapkan jemaat menerima Firman Tuhan, mereka dipimpin untuk menyanyikan lagu rohani, di sini seorang pemimpin pujian haruslah seorang yang sudah terbentuk dalam doa puasa, sehingga mempunyai kepekaan akan suara Roh Kudus. Dengan pimpinan Roh Kudus nyanyian gerejawi benar-benar mempersiapkan untuk masuk dalam Firman Tuhan dan ada hubungannya dengan Firman Tuhan dan jemaat dapat menerima Firman Tuhan dengan baik (I Kor. 14:15).

Pada saat Stephen Tong berusia 21 tahun, seorang hamba Tuhan yang tua berkata kepadanya, "Stephen Tong, seumur hidup $\mathrm{j}$ adilah seorang hamba $\mathrm{T}$ uhan yang mempunyai kuasa dalam pemberitaannya. Jangan hanya berbicara tanpa kuasa dalam pemberitaannya. Apa gunanaya? Bila engkau menghibur, orang yang dihibur harus sungguh-sungguh mendapat hiburan dari Roh Kudus. Bila engkau menegur, orang yang ditegur akan sungguh menyadari dosanya. Bila engkau mendidik, orang yang 
dididik akan sungguh-sungguh dididik." "31

Stephen Tong menjawab bahwa itu merupakan doanya, tetapi bagaimana bisa menjadi orang yang demikian? Carilah kemuliaan cahaya wajah Allah. Tuntutlah perjanjian dalam Firman-Nya. Jadilah seorang Hamba Tuhan yang sungguh dari Tuhan, jangan hanya menjadi seorang yang pintar berkhotbah, tetapi tidak ada kuasa di dalamnya. ${ }^{32}$ Seorang hamba Tuhan yang sungguh sungguh adalah hamba Tuhan yang hidup doanya disertai puasa.

Kedua, perkunjungan dan percakapan pastoral. Cara yang terbaik untuk mengetahui keperluan-keperluan jemaat adlah dengan berkunjung ke rumah mereka. Paulus mengetahui bahwa hal ini sangat penting. Paulus pergi dari rumah ke rumah (Kis. 20:18-28). Perkunjuangan Pastoral juga meliputi perkunjunagan kepada orang sakit di rumah sakit, orang yang dalam penjara dan kepada siapa saja. Perkunjungan ini merupakan alat utama dalam pelaksanaan penggembalaan dalam jemaat. Dalam perkunjungan ini bisa mengetahui, keperluan jemaat. Kunjungan mendatangkan manfaat bagi jemaat, jika bergantung sepenuhnya kepada Allah. Maka harus mengunjungi dalam roh doa. Seorang pelayan harus berdoa sebelum mengadakan kunjungan, supaya dapat mengunjungi dalam suasana doa. ${ }^{33}$

Ketiga, pelayanan doa syafaat. Doa syafaat adalah doa yang diucapkan oleh jemaat untuk semua orang (termasuk pemerintah) yang ada di dunia. Sejak dahulu doa ini memainkan peranan penting dalam penggembalaan. ${ }^{34}$ Doa syafaat yang benar di

${ }^{31}$ Stephen Tong, Keseimbangan Dalam Pelayanan Kristen (Surabaya: Yakin, 1976), 28.

${ }^{32}$ Ibid, 20.

${ }^{33}$ Ibid, 23.

${ }^{34}$ Ibid, 21. mana bergumul bersama-sama orang yang didoakan (dalam kesusahan, penderitaan mereka, dalam dosa mereka, dan lain-lain). Memohon syafaat untuk seseorang adalah turut mengambil bagian (partisipasi), dalam apa yang sedang $\mathrm{d}$ alami dalam hidupnya (Kej. 18:1633). Pelayanan doa syafaat sangat diperlukan untuk jiwa-jiwa yang terhilang. Beban ini perlu dinyatakan dengan penuh kesungguhan si dalam doa puasa. Kasih yang dari Allah membuat setiap orang menangis akan keselamatan jiwa-jiwa yang dinyatakan dalam doa puasa di mana harus tersungkurdalam tangisan Ilahi.

Keempat, pertumbuhan gereja. Gereja mula-mula bertumbuh dengan pesat, sebab ada kehidupan doa puasa, sehingga Roh Kudus bekerja dengan luar biasa (Kis. 2:41-47; 4:23-31; 13:1-2). Paul Yonggi Cho, seorang tokoh pertumbuhan gereja yang berhasil, mengatkan bahwa kunci kebangunan rohani: adalah doa. ${ }^{35}$ Gereja Korea memiliki bukit doa sebagai tempat pelaksanaan doa dan berpuasa, di tempat ini jemaat dan pelayan Tuhan berdoa syafaat dalam doa puasa untuk keselamatan jiwajiwa, sehingga gereja Korea diberkati Allah dengan luar biasa. Ketika Peter Wagner bertanya, apa sebabnya gereja Korea bertumbuh dengan pesat? Dengan sederhana mereka menjawab "Dari doa-doa itulah, kuasa Allah dicurahkan". ${ }^{36}$ Gereja bertumbuh karena kebangunan rohani yang dikerjakan Roh Kudus, yang merupakan hasil dari doa puasa.

Dari uraan di atas dapat disimpulkan bahwa relasi doa puasa dengan kepemimpinan penggembalaan adalah seorang hamba Tuhan yang sungguh

${ }^{35}$ Paul Yonggi Cho, Dimensi Keempat (Jakarta: YPI Imanuel 2014), 21.

${ }^{36}$ Ibid, 12. 
sungguh adalah hamba Tuhan yang hidup doanya disertai puasa. Kepemimpinan pengembalaan yang baik yang mempunyai pemahaman sebagai Pemimpin yang tahu jelas panggilannya sebagai Gembala. Pengkhotbah yang menjadikan doa puasa suatu faktor yang ampuh dalam kehidupan dan pelayanannya sendiri adalah orang yang kuat dalam pekerjaan Allah dan penuh kuasa untuk melebarkan Kerajaan Allah di dunia ini.

\section{Relasi Doa Puasa dalam Pertumbuhan Gereja}

Pelayanan pastoral adalah pelayanan penggembalaan. Kata "Pastor" berasal dari bahasa Latin yang berarti "Gembala". Di dalam bahasa Yunani "Poimen". Penggembalaan bisa disebut juga "Pastoralia" atau "Poimenika". Penggembalaan merupakan bagian dari Theologia-Praktika. Msweli dan Crider mengatakan bahwa penggembalaan adalah orang yang memelihara kawanan domba (umat) Allah. Ia memelihara sekelompok orang-orang Kristen. ${ }^{37}$ Hefst mengatakan bahwa tugas penggembalaan itu adalah: menolong orang satu persatu untuk menyadari hubungannya dengan Allah, dan mengajar orang untuk mengakui ketaatannya kepada Allah dan sesamanya dalam situasinya sendiri. ${ }^{38}$ Jadi inti dari penggembalaan adalah relasi antara si pelayan dan anggota-anggota jemaat.

Yesus memberikan teladan bahwa seorang gembala yang baik mengenal akan

\footnotetext{
${ }^{37}$ Seth Msweli dan Donals Crider, Pelayanan Pengembalaan. (Bandung: Kalam Hidup, 1974), 31.

${ }^{38}$ J.W. Hefst, Pastoral Ministry. https://www.tyndale.ca/seminary/stud $\mathrm{y} /$ pastoral-ministry
}

dombanya satu persatu, menjaganya, memelihara, membimbingnya, agar dombadombanya diselamatkan dari bahaya dan tidak tersesat. Dengan demikian, maka dalam pelayanan penggembalaan, Majelis Gereja dan pelayan-pelayan Tuhan menjadi penolong Gembala sidang dalam hal-hal rohani dan mengatur hal-hal jasmani (Kis. 6:1-6; 8:20; Rm. 12:7; 1 Kor. 12:28; Flp. 1:1) membantunya dalam mengunjungi dan menolong anggota-anggota yang sakit, yang miskin, serta anggota-anggota yang perlu ditolong baik dalam hal-hal rohani maupun jasmani (1 Tim. 3:8-13; Kis. 6:1-4; Rm. 16:1-2; I Tim. 3:11). Sebenarnya, yang diwajibkan kepada gembala sidang diwajibkan juga kepada Majelis Gereja dan pelayan-pelayan Tuhan; dan tuntutan rohani untuk keduanya juga sama, ikut juga bertanggung jawab dalam penggembalaan dengan penuh kesadaran dan takut akan Tuhan. Berkaitan hal tersebut, maka Storm merumuskan tugas penggembalaan itu adalah sebagai berikut: (1) Mencari dan mengunjungi anggota jemaat satu persatu. (2) Mengabarkan Firman Allah kepada mereka, dalam situasi hidup mereka pribadi. (3) Melayani mereka, sama seperti sekiranya Yesus melayani mereka. (4) Supaya mereka lebih menyadari akan iman mereka, dan dapat mewujudkan iman itu dalam hidupnya sehari-hari. ${ }^{39}$ Jika gereja hidup bersama Kristus dan mengalami kehadiran-Nya, maka timbullah belas kasihan, kepedulian, dan kerinduan untuk melayani dalam diri jemaat-Nya. ${ }^{40}$

\footnotetext{
${ }^{39}$ M. Bons Storm, Kuasa Doa (Surabaya: Yakin, 1983), 79.

${ }^{40}$ Dorce Sondopen, Relasi Antara
} Penginjilan Dan Pemuridan Untuk Pertumbuhan. Excelsis Deo: Jurnal Teologi, Misiologi, dan Pendidikan Vol.3, No. 2, 95-105. http://ejournal.sttexcelsius.ac.id/index.php/excelsisdeo/articl e/view/18/16 
Pelayanan Pastoral harus mempunyai tujuan. Kalau ia tidak mempunyai tujuan, maka pelayanan akan menjadi rutinitas dan membosankan. Ada lima tujuan gereja yang sangat penting sebagai berikut: Pertama, kedewasaan rohani. Umat Tuhan bukan ditentukan dengan gedung gereja yang megah tetapi oleh kedewasaan dan kekudusan umat Tuhan. Kekudusan ini hanya oleh anugerah kepala gereja yaitu Tuhan Yesus. Sebagai umat Tuhan ia perlu berjuang melatih dirinya untuk menjadi seperti Kristus dalam setiap bidang kehidupannya. Dalam pelayanan penggembalaan dapat menolong menyadari kebutuhan akan kedewasaan dan mendorong bertumbuh dalam kerohanian. ${ }^{41}$ Kedua, jemaat missioner. Dalam Lukas 14:23 Yesus mengatakan, bahwa rumah-Nya harus penuh, Yang dimaksudkan adalah Kerajaan Allah. Sebelum Yesus naik ke Surga Ia memberikan amanat Agung yaitu: Beritahukanlah Injil sampai ke ujung bumi, dan amenjadikan murid. Gereja harus terlibat dalam misi ini (Mat. 28:19-20). Cho Yonggi berkata, kena gereja tidak bertumbuh, sebab gereja itu hanya memikirkan dirinya sendiri, ia tidak pernah melihat jiwa-jiwa yang terhilang. ${ }^{42}$ Pembangunan Jemaat. Rasul Paulus sangat memperhatikan pembangunan jemaat. Paulus mengunjungi jemaat-jemaat dan menulis surat-surat untuk jemaat. Dalam surat Paulus terdapat penggembalaan yang membangun jemaat. Umat Tuhan kalau dibangun, maka tiap-tiap anggota menjadi anggota yang hidup, yang tahu akan panggilannya, jemaat menjadi hidup dan

\footnotetext{
${ }^{41}$ Ishak Lew, Membangun Sidang Jemaat (Surabaya: Sekolah Elkitab Surabaya, 1981), 89.

${ }^{42}$ Cho Yonggi, Doa Kunci Ke Arah Kebangunan Rohani (Jakarta: YPI Imanuel, 1986), 98.
}

bergerak. Dalam 1 Korintus 12:4-17 menggambarkan tentang pelayanan dalam tubuh Kristus. Tiap-tiap anggota terpanggil untuk mewujudkan imannya, menurut bakat-bakat yang diberikan kepadanya. Dengan demikian yang satu dapat amenyempurnakan yang lain, sehingga jemaat dapat dibangun. Penggembalaan perlu memberikan bimbingan kepada jemaat, untuk dapat mengetahui panggilannya, menjadi orang yang tepat pada tempatnya, bagaimana mereka bisa hidup sebagai pengikut Kristus dengan bakat yang diberikan oleh Tuhan dan panggilan dalam kehidupan mereka. Ketiga, memperhatikan jemaat. Paulus memperhatikan jemaat, kalau tidak sempat amengunjungi, ia menulis surat. Dalam surat-suratnya ia memberikan nasehat, menyatakan kasih, keinginannya untuk bertukar pikiran, menganjurkan tolongmenolong, saling membimbing dan menyokong. Menggembala jemaat haruslah mempunyai tujuan untuk memperhatikan kesulitan, kebutuhan, kesusahaan mereka dan mengarahkan, juga membimbing untuk mendapat jalan keluar. Keempat, Yesus dimuliakan. Yesus adalah kepala gereja. Tubuh harus senantiasa tidak lepas dari kepala (1 Kor. 12:12-31). Penggembalaan harus mempunyai tujuan utama yaitu semata-mata untuk kemuliaan Tuhan Yesus. Yesus menjadi pusat penggembalaan dan tujuan penggembalaan.

Berdasarkan keterangan-keterangan yang telah dipelajari, maka relasi doa puasa dengan pertumbuhan gereja adalah pelayanan penggembalaan dapat menolong menyadari kebutuhan akan kedewasaan dan mendorong bertumbuh dalam kerohanian. Umat Tuhan kalau dibangun, maka tiap-tiap anggota menjadi anggota yang hidup, yang tahu akan panggilannya, jemaat menjadi 
hidup dan bergerak, umat Tuhan bukan ditentukan dengan gedung gereja yang megah tetapi oleh kedewasaan dan kekudusan umat Tuhan. Kekudusan ini hanya oleh anugerah kepala gereja yaitu Tuhan Yesus. Penggembalaan perlu memberikan bimbingan kepada jemaat, untuk dapat mengetahui panggilannya, menjadi orang yang tepat pada tempatnya, bagaimana mereka bisa hidup sebagai pengikut Kristus dengan bakat yang diberikan oleh Tuhan dan panggilan dalam kehidupan masing.

\section{KESIMPULAN}

Dari uraian di atas dapat disimpulkan sebagai berikut: Pertama, berpantang dengan semua makanan jasmani untuk tubuh yang lain menggambarkan akibat berpuasa, yaitu: "penderitaan jiwa". Puasa menghilangkan kesenangan tubuh secara sukarela dan merendahkan jiwa untuk maksud-maksud rohani.

Kedua, relasi doa puasa dengan Roh Kudus adalah doa puasa mendatangkan kejernihan jalan, akan suara roh, sehingga akan peka dengan suara Roh Kudus untuk memberikan bimbingan memperoleh kemenangan rohani dan materi juga. Maka perlu adanya persekutuan dengan Roh Kudus. Persekutuan Roh Kudus memimpin tiap hari dan persekutuan terus menerus dengan Roh Kudus penting untuk kesejahteraan rohani. Roh Kudus memimpin hati ke dalam anugerah dan cinta, iman. Roh Kudus sebagai sahabat setia yang datang untuk melakuklan segala sesuatu yang disebutkan firman akan dilakukan-Nya.

Ketiga, relasi doa puasa dengan kepemimpinan pengembalaan adalah seorang hamba Tuhan yang sungguh sungguh adalah hamba Tuhan yang hidup doanya disertai puasa. Kepemimpinan pengembalaan yang baik yang mempunyai pemahaman sebagai Pemimpin yang tahu jelas panggilannya sebagai Gembala. Pengkhotbah yang menjadikan doa puasa suatu faktor yang ampuh dalam kehidupan dan pelayanannya sendiri adalah orang yang kuat dalam pekerjaan Allah dan penuh kuasa untuk melebarkan Kerajaan Allah di dunia ini.

Keempat, relasi doa puasa dalam pertumbuhan Gereja adalah pelayanan penggembalaan dapat menolong menyadari kebutuhan akan kedewasaan dan mendorong bertumbuh dalam kerohanian. Umat Tuhan kalau dibangun, maka tiap-tiap anggota menjadi anggota yang hidup, yang tahu akan panggilannya, jemaat menjadi hidup dan bergerak, umat Tuhan bukan ditentukan dengan gedung gereja yang megah tetapi oleh kedewasaan dan kekudusan umat Tuhan. Kekudusan ini hanya oleh anugerah kepala gereja yaitu Tuhan Yesus. Penggembalaan perlu memberikan bimbingan kepada jemaat, untuk dapat mengetahui panggilannya, menjadi orang yang tepat pada tempatnya, bagaimana mereka bisa hidup sebagai pengikut Kristus dengan bakat yang diberikan oleh Tuhan dan panggilan dalam kehidupan masing.

\section{DAFTAR PUSTAKA}

Abineno.J. L. Ch. Pelavanan dan Pelavan Jemaat Jemaat Dalam Perjanjian Baru. Jakarta: BPK Gunung Mulia, 1986.

Beal, James. Lee. Puasa. Bandung: Penerbit Kalam Hidup, 1980.

Bounds, E. M. Power Through Prayer. New York; Simon and Schuster, 1997.

Cho, Paul. Yonggi. Doa Kunci Ke Arah Kebangunan Rohani. Jakarta: YPI Immanuel, 1986. 
Cho, Paul. Yonggi. Dimensi Keempat Jakarta: YPI Imanuel 2014.

Cho, Paul. Yonggi. Roh Kudus Adalah Mitra Saya. Jakarta: YPI Imanuel, 2002.

Darmaputera, Eka. Kepemimpinan Kristiani. Jakarta: STT Jakarta, 2001

D'Sauza. Anthonv. Developing The Leader Within You, Strategies for Effective Leadership. Singapore: Haggai Centre for Advanced Leadership Studies, 1994.

Faber, H. Pastoral Ministry. Surabaya: Yakin, 1981.

Flory, R.D. Tuntunan Doa Puasa, New York: Used - Acceptable, 2000.

GP, Harianto. Studi Etika Pendidikan Tentang Proses Belajar-Mengajar Yang Mengubah Karakter Dan Kurikulum 2013. Stulos. Vol. 12. No. 1 39-64. http://www.sttb.ac.id/download/stulos/ 2013/April/Stulos.

Haggai John., Lead On! Leadership That Endures in A changing World. (Waco Texas: World Publishing, 1986.

Hefst, J.W. Pastoral Ministry. https://www.tyndale.ca/seminary/stud $\mathrm{y} /$ pastoral-ministry

J.Verkuyl Khotbah di Bukit. Jakarta: BPK Gunung Mulia, 1989.

Kurniasari, Debora. Pengerja Mimbar. Surabaya: Diktat Sekolah Elkitab Surabaya, 1980.

Lew, Ishak. Membangun Sidang Jemaat. Surabaya: Sekolah Elkitab Surabaya, 1981.

Mimery, Nehemiah. Rahasia Tentang Doa. Jakarta: Nehemiah Mimery Press, 1969.

Msweli. Seth.. \& Donals. Crider. Pelavanan Pengembalaan. Bandung: Kalam Hidup, 1974.

Sondopen, Dorce. Relasi Antara Penginjilan Dan Pemuridan Untuk Pertumbuhan. Excelsis Deo: Jurnal Teologi, Misiologi, dan Pendidikan Vol.3, No. 2, 95-105. http://e-

journal.sttexcelsius.ac.id/index.ph p/excelsisdeo/article/view/18/16

Storm, M. Bons. Kuasa Doa Surabaya: Yakin, 1983.

Stott, R.W. John. Khotbah di Bukit. Jakarta: Yayasan Komunikasi Bina Kasih/OMF, 1990.

Subekti. Timotius. Khotbah Tuhan Yesus Pembentuk Karakter Ilahi Yogjakarta: Andi, 1986.

Sudomo, Ciri Utama Kepemimpinan Sejati. Jakarta: CBA Indonesia, 2005.

Tong, Stephen. Keseimbangan Dalam Pelayanan Kristen. Surabaya: Yakin, 1976.

Wallis, Arthur. God's Chosen Fast. Pennsylvania: Christian Literature Crusade, 1971. 